\title{
Retroperitoneal fibrosis associated with pancreatic disease
}

\author{
A. JOHN WEBB* \\ M.B., Ch.B., F.R.C.S. \\ P. Dawson-Edwards \\ M.B., Ch.B., F.R.C.S. \\ Senior Surgical Registrar \\ Consultant Surgeon and Urologist \\ Queen Elizabeth Hospital, Birmingham
}

EMPHASIS in the literature of retroperitoneal fibrosis is rightly directed towards the urinary tract as this is where its most serious effects are produced (Raper, 1956; Talbot \& Mahoney, 1957).

Gastro-intestinal symptoms may characterize the early stage of the illness and a gastro-intestinal tract origin cannot be excluded (Ormond, 1965). In addition, the duodenum, pancreas, mesenteric root, small and large bowel may be involved by the fibrosis (Paull, Causey \& Hodges, 1955).

Our studies on a total of fifteen patients with retroperitoneal fibrosis have indicated that the benign and malignant forms are difficult to distinguish.

In two patients, the fibrosis was clearly associated with pancreatic lesions one benign and the other malignant-and each demonstrates the usual problems in diagnosis and management (Hume, Erb \& Stevens, 1963).

\section{Case No. 1: Miss R.A., age 20}

A mild abdominal injury sustained in October 1961 while playing hockey, was followed by some lumbo-dorsal discomfort. In October 1962 this girl presented with polydipsia, frequency of micturition, left loin and groin pain dating back some months. A tender mass was felt in the left loin and an IVP showed poor renal function on the left side with a left ureteric block on retrograde pyelography at lumbar 2 level. Surgical exploration was advised.

\section{Operation (P.D.E., 6 October 1962)}

Through a left renal incision, a hard mass was found involving the aorta, duodeno-jejunal flexure and left renal hilum. Malignancy was diagnosed but the histological report was that of fibrous inflammatory tissue. Abdominal exploration disclosed a thick-walled cyst originating from the pancreatic body; $50 \mathrm{ml}$ of glairy fluid was aspirated and tube drainage was instituted. Histological examination demonstrated epithelium consistent with a pancreatic origin. The diagnosis of a traumatic pancreatic cyst was made. Thereafter a persistent urinary infection with $E$. coli and Staph. albus developed. Intermittent

\footnotetext{
*Present address: Bristol Royal Infirmary.
}

mild loin pain persisted and in December 1962 nausea, vomiting, lassitude, backache and right-sided abdominal pain returned with a palpable left hypochondrial mass.

An intravenous pyelogram in March 1964 showed good right-sided secretion but on the left side, nonfunction and a minimum of renal tissue. At this stage, $\mathrm{Dr}$ W. Trevor Cooke undertook a full gastro-intestinal investigation.

\section{Investigations}

Haemoglobin, $70 \%$.

Serum urea, $18 \mathrm{mg} / 100 \mathrm{ml}$. Serum albumin, $4 \cdot 4 \mathrm{~g} / 100 \mathrm{ml}$. Serum globulin, $3 \cdot 1 \mathrm{~g} / 100 \mathrm{ml}$.

Barium enema: Extrinsic compression of the hepatic flexure was noted.

Barium meal and small bowel studies: The stomach was displaced anteriorly with partial extrinsic obstruction of the duodenal third part.

On 22 June 1964 laparotomy confirmed a left abdominal cystic mass ( 4 in. diameter) arising from the pancreatic body, with evidence of early portal hypertension. Internal drainage of the cyst into the stomach was performed. In spite of adequate hydration, the patient became anuric with right loin pain and tenderness. Retrograde pyelography showed ureteric obstruction.

Exploration on 12 July 1965 revealed a right ureteric block from fibrous tissue at L.3 level extending across the mid-line from the left side. The ureter was completely freed, with intra-peritoneal transposition.

Her progress was poor with recurrent right loin pain and urinary infection; intravenous and retrograde pyelography in November 1964 confirmed further right ureteric block, on this occasion at the pelvic brim. The serum urea level was $88 \mathrm{mg} /$ $100 \mathrm{ml}$, haemoglobin $58 \%$.

\section{Operation, 23 November 1964}

This confirmed the new site of obstruction some $5 \mathrm{~cm}$ below the previous narrowing. Ureterolysis and a further intraperitoneal transposition was performed but the ureter was noted to be involved in the fibrotic process (Fig. 1).

An intravenous pyelogram in March 1965 showed 


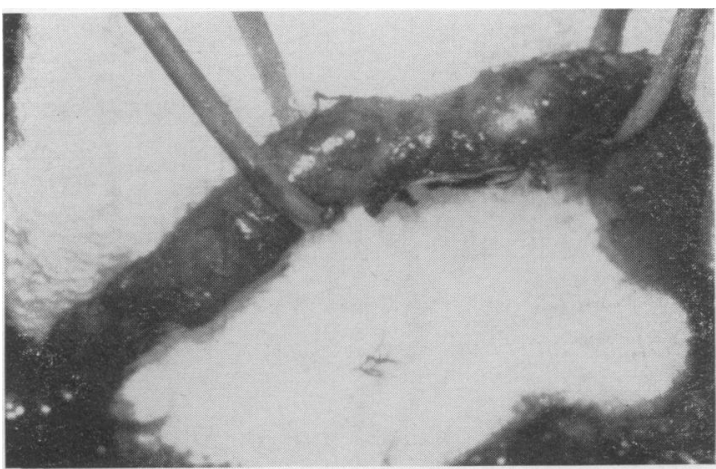

Fig. 1. The extremely thickened, fibrotic right ureter following the second ureterolysis in November 1964.

improvement on the right side but because of her precarious renal function, a left-sided ureterolysis was carried out. This extended over $10 \mathrm{~cm}$, requiring a considerable intraperitoneal transposition. The left kidney was encased in fibrous tissue and to date no function has reappeared. Her pyuria with $E$. coli infection persists.

\section{Investigations}

Serum albumin, $3.9 \mathrm{~g} / 100 \mathrm{ml}$. Serum globulin, $3.9 \mathrm{~g} / 100 \mathrm{ml}$.

Electrophoresis: raised alpha 3 and gamma fractions.

Intravenous pyelography (November 1965) demonstrated dilated and blunted calyces on the right side (Fig. 2).

\section{Comment}

The extensive and crippling fibrosis in this girl is considered to be the sequel of a traumatic pancreatitis with cyst formation. In common with other reports, malignancy was suspected at the first operation (Dineen, Asch \& Pearce, 1960; Samellas, 1961). A connection between fibrosis and trauma has been suggested but not clearly substantiated in the reports of MacLean (1954) and Hackett (1958).

The operative appearance of portal hypertension together with the radiological evidence of duodenal and colonic obstruction is of interest. Portal hypertension has been reported by Inkley \& Abbot (1961), Eiseman \& Yeoh (1962) and Schneider (1964); bleeding from oesophageal varices may develop. The first report of biliary tract involvement was that of Raper (1956) but others have followed (McMillan, Swarts \& Knudtson, 1964; Hardy, 1962) and retroperitoneal fibrosis appears to be one form of sclerosing cholangitis (Bartholomew et al., 1963). In another case from our series hepato-splenomegaly with irregular fatty change and portal round-cell infiltration was present in the liver biopsy (Webb \& Dawson-Edwards, 1966).

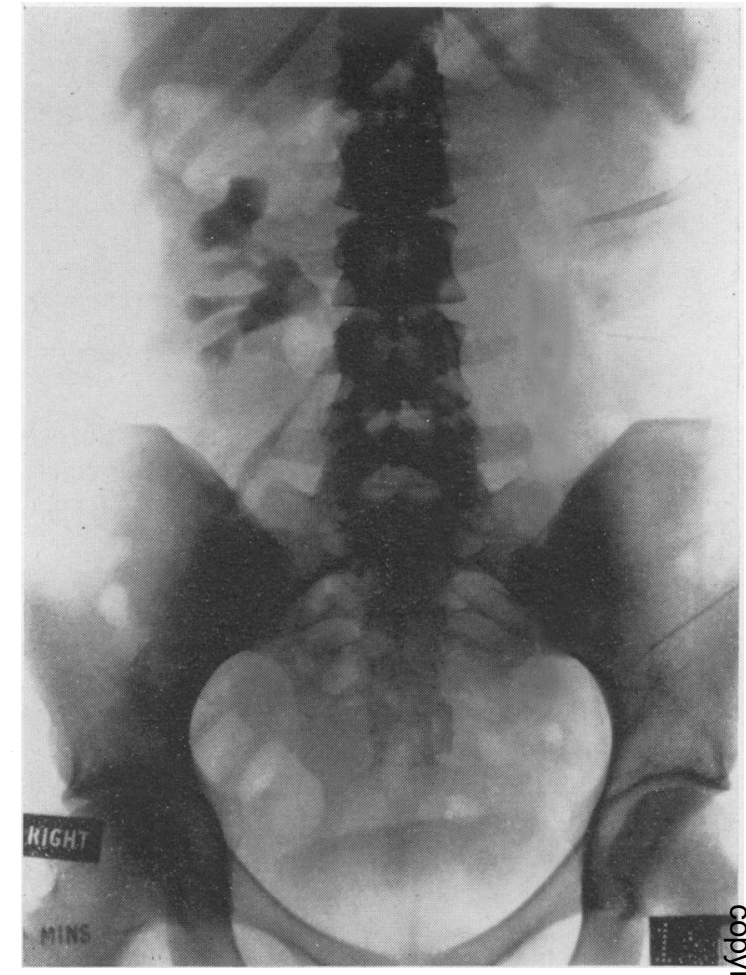

Fig. 2. Case 1 : Intravenous pyelogram (November 1965) (10-min film) showing the dilated, blunted calyces and transposed ureter. No function is present on the left.

Intra-abdominal fibrosis may be very extensive and either diffuse or nodular in form. Patoir \& Spy (1962) described a case with recurrent icterus, hepatomegaly and radiological evidence of duodenal and transverse colon deviation and compression. At laparotomy the fibrotic plaque extended to the diaphragm and involved the mesenteric root and colon.

It appears that by the time this girl developed anuria her left kidney was irretrievably damaged. Her present state of chronic pyelonephritis gives cause for concern and urinary diversion by a ureteroileo-cystoplasty (Hache, Utz \& Woolner, 1962) may be required or alternatively, ureterotomy and T-tube drainage (Marion, 1935; MacKelvie \& McKelvie, 1963). The functional recovery of fibrotic ureters is uncertain and deserves further study.

\section{Case No. 2: Mr L.S., age 54}

For 10 years this man had suffered intermittent epigastric pain appearing an hour after meals; antacids had been prescribed on suspicion of a duodenal ulcer. In February 1965 severe pain had persisted for 10 weeks with associated vomiting and one episode of melaena. He had experienced 
aching in the hips, thighs and buttocks for 3 years. A left orchidectomy had been performed in 1942 for seminoma. Examination elicited epigastric tenderness. Many investigations were carried out under the care of Dr Trevor Cooke, and some relevant ones are as follows:

Haemoglobin, $90 \%$. WBC, $10,000 / \mathrm{mm}^{3}$, normal differential count.

Serum proteins, $6.59 \mathrm{~g} / 100 \mathrm{ml}$. Albumin, 4.95 $\mathrm{g} / 100 \mathrm{ml}$. Globulins, $2.59 \mathrm{~g} / 100 \mathrm{ml}$.

Faecal fat estimations, $4.3 \mathrm{~g} / \mathrm{fat} / 24 \mathrm{hr}$ excretion.

Serum amylase, 204 units. Serum bilirubin, $0 \cdot 2 \mathrm{mg} / 100 \mathrm{ml}$.

Serum calcium, $9.5 \mathrm{mg} / 100 \mathrm{ml}$. Serum phosphorus, $4 \cdot 1 \mathrm{mg} / 100 \mathrm{ml}$.

Several mid-stream urine examinations: $E$. coli cultured on occasions.

A barium meal examination showed no duodenal ulcer but outlined a calcified lesion with small scattered satellite opacities. A pancreatic or renal lesion was suspected and intravenous pyelogram produced normal right-sided function with none on the left (Fig. 3). In view of these findings, he was transferred to the care of one of us (P.D.E.). Further questioning established that for a year



FIG. 3. Intravenous pyelogram (15-min film) showing good right-sided function but a medially deviated ureter. The rounded but irregularly calcified lesion, with satellite opacities also demonstrated.


FIG. 4. Views of the retrograde pyelogram; the ureteric obstruction is seen in relation to the calcified pancreatic tumour. 
bilateral loin, groin and hip pain had been increasing with vomiting and frequency of micturition.

On examination the blood pressure was $140 / 110$ $\mathrm{mmHg}$, with left loin tenderness; the serum urea level was $65 \mathrm{mg} / 100 \mathrm{ml}$.

Cystoscopy (25 August 1965) indicated some increase in vascularity at the bladder base and easy passage of a ureteric catheter to the left renal pelvis. Retrograde pyelography showed a ureteral stenosis $1.5 \mathrm{~cm}$ below the left pelvi-ureteric junction (Fig. 4). The calcification was regarded as perinephric; possibly a chronic tuberculous abscess. Operation was performed (1 September 1965) through a left loin incision without a firm pre-operative diagnosis. The left kidney was hydro-nephrotic with a large rock-hard mass arising from the pancreatic body lying to the medial side of the renal pelvis. The appearances were those of a pancreatic tumour. The peritoneum was opened and the lesion deemed to be irremovable. Further assessment showed retroperitoneal fibrosis to be present extending across the mid-line and appearing to deviate the aorta to the right side. The left ureter was involved in fibrosis over some $4 \mathrm{~cm}$ length and ureterolysis was performed (Fig. 5). The ureteric wall was thickened. In addition to the fibrosis some myxomatous tissue was curetted from between the ureter and the calcified mass. This was submitted to both histological and cytological examination. The histological report described masses of mucin, containing haematoxophil granules and cellular fibrous tissue with clumps of a regular low columnar epithelium. The origin of these cells was obscure but neoplasia was not apparent.

His post-operative recovery was good. The serum proteins and electrophoretic strip were examined and found to be normal. His serum urea level remained slightly elevated to $60 \mathrm{mg} / 100 \mathrm{ml}$.

\section{Progress report}

In November 1965 the patient complained of lumbo-sacral pain; radiologically Paget's disease of the sacrum was probable but the pain could equally have been due to the retroperitoneal plaque. Intravenous pyelography failed to show a return of function.

\section{Comment}

A biopsy of the actual pancreatic tumour was not taken, as specimens from around the ureter and the plaque were considered to be adequate for diagnostic purposes. Both fibrous tissue and calcified myxomatous tumour were obtained. Whereas the histological opinion on this latter material did not exclude malignancy, a cytological assessment on smears made from it was definite (Class $\mathrm{V}$ diagnosis). Amidst a PAS positive stroma were groups of

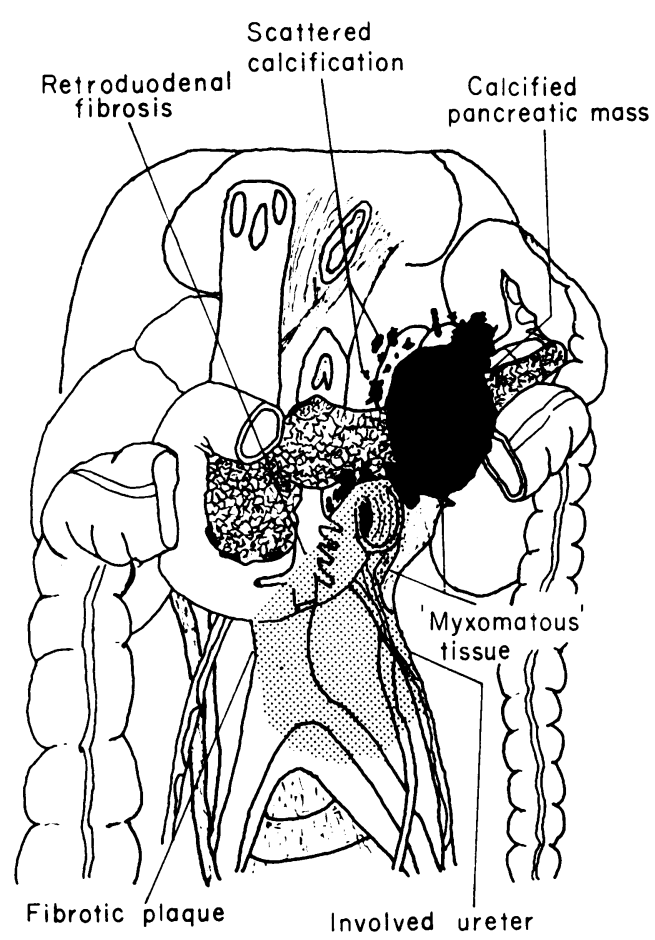

Fig. 5. Case 2: Diagrammatic representation of the pancreatic tumour and retroperitoneal plaque found at operation.

malignant cells consistent with a pancreatic origin (Figs. 6 and 7).

The clinical presentation of epigastric pain simulating a duodenal ulcer is characteristic of cystic pancreatic tumours (Cornes \& Azzopardi, 1959); likewise the episode of melaena occurring earlier in the year. The mechanism of intestinal bleeding is discussed by Campbell \& Cruickshank (1962) who invoke either on erosive gastritis from local pressure or local invasion.

The radiological appearances are particularly clear and post-operative re-assessment suggests they are typical of a pancreatic cyst-adenocarcinoma. Cystadenoma of the pancreas is a rare tumour and carcinomatous change even more unusual (Speese, 1915; Lichenstein, 1934; Smith, 1958). The satellite calcification in our case is notable and is a firm indication of local malignant spread with focal deposits of calcium. The calcification was confirmed by a Von Kossa stain for phosphate on the histological material. Haukol \& Melamed (1950) reported two malignant pancreatic cysts both of which demonstrated irregular fragmentary and spicule calcification. They regarded calcification as an important radiological diagnostic feature and in one of the cases reported by Cornes \& Azzopardi 


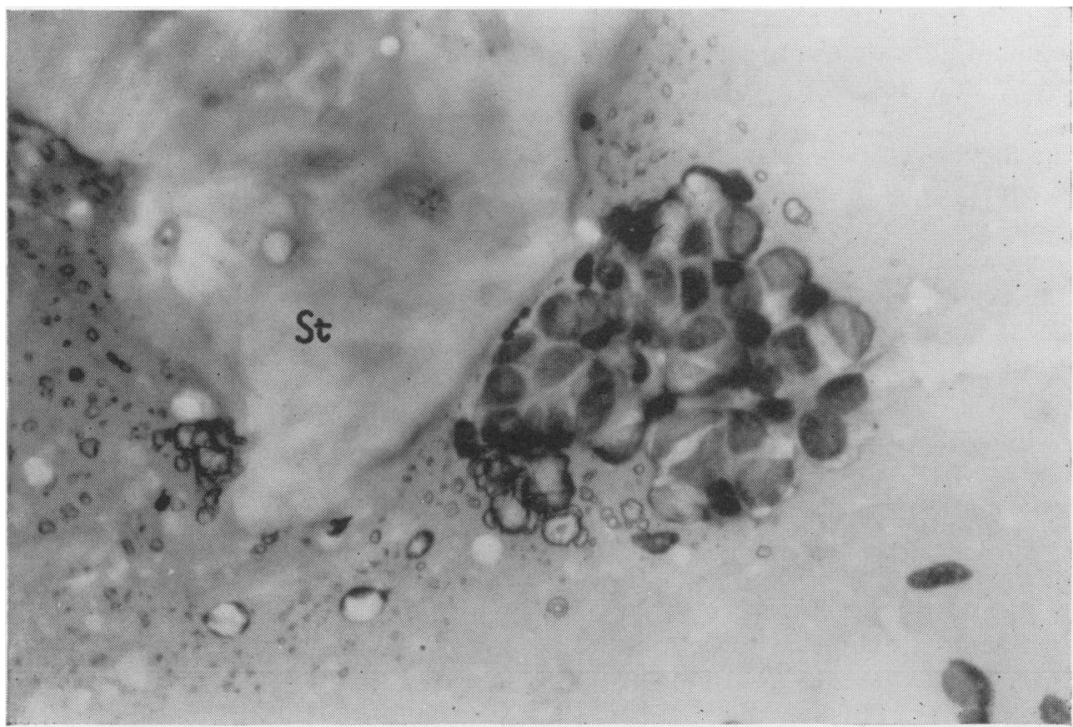

FIG. 6. Case 2: Cytological smear of the peri-ureteric tissue. The PAS positive stroma (St) and calcified granules are seen on the left with a group of malignant cells showing an acino-papillary pattern. Jenner-Giemsa, $\times 320$.

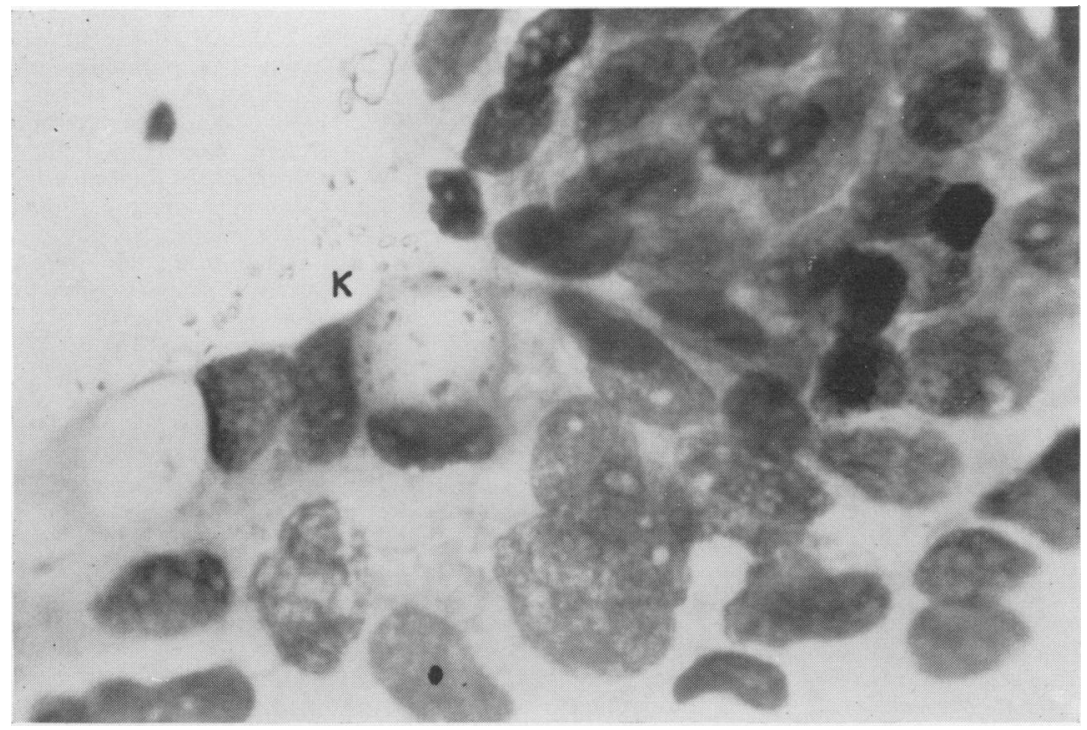

FIG. 7. Case 2: Cytological view of the epithelial cells. Apart from their obvious malignancy these appearances are consistent with a carcinoma of pancreatic origin. A malignant karyorrhexis is seen $(\mathrm{K})$. Jenner-Giemsa, $\times 800$.

(1959) the rim of the cyst was thinly outlined. Campbell \& Cruickshank (1962) reported the largest series in the literature of fourteen cystadenomata and three cystadenocarcinomata-in only two were foci of calcification seen and these were microscopic.
Cullen, Remine \& Dahlin (1963) reporting sixteen cases of cystadenocarcinoma from the Mayo Clinic, do not mention calcification but note the thick colloid jelly-like material found in these tumours. Warren, McDonald \& Veidenheimer (1964) collected 148 cystic pancreatic lesions from 
the Lahey Clinic of which twelve were cystadenocarcinomata; three had appeared in the last 8 years; the 5-year survival rate following all forms of surgery was $43 \%$.

Local spread in the form of mucoid deposits, as in our case, is most exceptional. Willis (1960) records an example of mucoid secondaries in the cisterna chyli, lungs and hilar lymph nodes. The primary was a mucus-secreting pancreatic carcinoma; retroperitoneal fibrosis was not present.

Pancreatic lesions have been reported as confusing a urological diagnosis; Ormond, Wadsworth \& Morley (1943) quoted a patient where the right urinary tract was symptomatic from and grossly distorted by a cystic tumour in the pancreatic head. Thompson \& Culp (1963) describing nine perplexing cystic masses near the kidney, include one pancreatic cystadenocarcinoma and one calcified cystic hypernephroma. This present case appears to be the first report of retroperitoneal fibrosis resulting from myxomatous deposits of pancreatic cystadenocarcinoma although pancreatic carcinoma was found at autopsy in the patient reported by Kaude (1966).

\section{Acknowledgments}

We wish to thank Mr T. Dee for invaluable photographic assistance. The cytological investigations are supported by grants from the Ernest and Minnie Dawson Cancer Trust and the University of Birmingham Cancer Research Fund.

\section{References}

Bartholomew, L.G., Cain, J.C., Woolner, L.B., Utz, D.C. \& FERrIS, D.O. (1963) Sclerosing cholangitis, its possible association with Riedel's Struma and fibrous retroperitonitis. Report of 2 cases. New Engl. J. Med. 269, 8.

Campbell, J.A. \& Cruickshank, A.H. (1962) Cystadenoma and cystadenocarcinoma of the pancreas. J. clin. Path. 15, 432.

Cornes, J.S. \& Azzopardi, J.G. (1959) Pancreatic cystadenoma and cystadenocarcinoma. Brit. J. Surg. 47, 139.

Cullen, R.K., JR., Remine, W.R. \& Dahlin, D.C. (1963) A clinicopathological study of cystadenocarcinoma of the pancreas. Surg. Gynec. Obstet. 117, 189.

Dineen, J., Asch, T. \& Pearce, J.M. (1960) Retroperitoneal fibrosis. Radiology, 75, 380.

Eiseman, B. \& YeOH, K.S. (1962) Portal hypertension associated with idiopathic fibrosis. Brit. J. Surg. 50, 225.

Hache, L., Utz, D.C. \& WoOlneR, L.B. (1962) Idiopathic fibrous retroperitonitis. Surg. Gynec. Obstet. 115, 737.

HaCKeTt, E. (1958) Idiopathic retroperitoneal fibrosis, a condition involving the ureters, aorta and inferior vena cava. Brit. J. Surg. 46, 3.

HARDY, J.D. (1962) Some lesions of the biliary tree. Idiopathic retroperitoneal fibrosis and other problems. Amer. J. Surg. 103, 457.
Haukol, R.S. \& Melamed, A. (1950) Cystadenoma of the pancreas. A report of two cases showing calcification. Amer. J. Roentgen. 63, 234.

Hueston, J.T. (1965) Dupuytren's contracture. Ann. roy. Coll. Surg. Engl. 36, 134.

Hume, H.A., ERB, W.H. \& Stevens, L.W. (1963) Idiopathic retroperitoneal fibrosis. Amer. J. Surg. 105, 699.

INKLEY, S.R. \& ABвOTT, G.R. (1961) Unilateral pulmonary arteriosclerosis. Arch. intern. Med. 108, 903.

KAUDE, J. (1966) Retroperitoneal fibrosis. Acta radiol. (Stockh.), 4, 331.

Lichenstein, L. (1934) Papillary cystadenocarcinoma of pancreas. Amer. J. Cancer, 21, 542.

LUND, M. (1941) Dupuytren's contracture and epilepsy. Acta psychiat. scand. 16, 465.

MacKelvie, A.A. \& MCKelvie, G.B. (1963) Retroperitoneal fibrosis with unilateral renal hypertension. Scott. med. J. $8,112$.

MaCLEAN, J.T. (1954) Unusual conditions of the ureter and kidney. Brit. J. Urol. 26, 127.

McMillan, J.C., Swarts, C.J. \& Knudtson, K.P. (1964) Idiopathic fibrous retroperitonitis-a report of 10 new cases. Northw. Med. (Seattle), 63, 605.

MARIONं, M. (1935) Un cas interessant de chirurgie ureterale. Bull. Soc. franc. Urol. 72.

ORMOND, J.K. (1965) Idiopathic retroperitoneal fibrosis. Discussion on aetiology. J. Urol. 94, 385.

Ormond, J.K., WADSWORTH, G.H. \& MORLEY, H.V. (1943) Pancreatic lesions confusing urologic diagnosis. J. Urol. (Baltimore), 48, 650.

PAtolR, M. \& SPY, J. (1962) Fibrose retro-peritoneale. J. Urol. Nephrol. 68, 702.

Paull, D.P., Causey, J.C. \& Hodges, C.V. (1955) Perinephritis plastica. J. Urol. (Baltimore), 73, 212.

PugH, R.C.B. (1960) The pathology of fibrotic lesions Proc. roy. Soc. Med. 53, 685.

RAPER, F.P. (1956) Idiopathic retroperitoneal fibrosisinvolving the ureters. Brit. J. Urol. 28, 436.

Samellas, W. (1961) Ureteric obstruction due to compression by an idiopathic retroperitoneal inflammatory process. J. Urol. (Baltimore), 85, 928.

SCHNEIDER, C.F. (1964) Idiopathic retroperitoneal fibrosis producing vena caval, biliary, ureteral and duodenal obstructions. Ann. Surg. 159, 316.

Sмiтh, R. (1958) Cancer (Ed. by R. W. Raven), vol. 2, p. 186. Butterworth, London.

SpeEse, J.J. (1915) Cystadenoma of the pancreas with extension to the abdominal wall ten years after drainage of a pancreatic cyst. Ann. Surg. 61, 759.

Suby, H.I., Kerr, W.S., JR., Graham, J.R. \& Fraley, E. (1965) Retroperitoneal fibrosis. A missing link in the chain. J. Urol. (Baltimore), 93, 144.

TALBOT, H.S. \& MAHONEY, E.M. (1957) Obstruction of both ureters by retroperitoneal inflammation. J. Urol. (Baltimore), 78, 738.

Thompson, G.T. \& Culp, O.S. (1963) Perplexing cystic masses near the kidney. J. Urol. (Baltimore), 89, 370.

WARren, K.W., MCDonald, W.M. \& Veidenheimer, M.C. (1964) Trends in pancreatic surgery. Surg. Clin. N. Amer. 44, 743.

WebB, A.J. \& Dawson-Edwards, P. (1966) Fulminating retroperitoneal fibrosis with pericystitis plastica. Brit. J. Urol. (In press).

Willis, R.A. (1960) Pathology of Tumours, 3rd edn, p. 449. Butterworth, London. 